The following were elected Officers and members of the Council for the coming year: Dr. A. J. Taylor (President); Mr. R. M. Robbins(Treasurer); Professor J. D. Evans (Director); Dr. I. H. Longworth (Secretary); Mr. D. F. Allen; Dr. R. L. S. Bruce-Mitford; Mr. A. R. Dufty; Mr. P. A. Faulkner; Mr. B. J. Greenhill; Professor R. M. Harrison; Mr. T. G. Hassall; Dr. G. W. Herrmann; Mr. R. R. Inskeep; Mr. W. Reid; Dr. G. G. Simpson; Mr. P. Smith; Mr. B. H. I. H. Stewart; Dr. H. M. Taylor; Professor W. Watson; Mrs. L. Webster; Dr. N. J. Williams.

The President then delivered his Anniversary Address (pp. I-IO).

Ist May 1975. The President announced that he had appointed Mr. A. R. Dufty to be a Vice-President.

Mr. N. H. Cooper, Mr. C. A. F. Meekings, Miss N. R. Briggs, Mr. D. C. Winfield, Mr. C. B. Burgess, Mr. A. G. Down, Dr. J. W. Hayes, Dr. R. N. Bailey, Dr. A. Saunders, Dr. J. E. Herrin, Dr. R. S. Cormack, Mr. J. F. Physick, Mr. J. Christian, Mr. P. J. Reynolds, Professor E. T. Hall, Mr. D. Peace, Dr. D. M. Smith, Professor L. Thorpe, and Professor J. Simmons were elected Fellows.

8th May 1975. The Norman church and door at Stillingfleet, Yorkshire, by P. V. Addyman and Ian Goodall.

A selection of brief obituaries covering the period $1973-5$ follows.

\title{
HIS MAJESTY KING GUSTAF VI ADOLF OF SWEDEN
}

\section{Elected Royal Fellow rath December 1935}

King Gustaf VI Adolf of Sweden died at Helsinborg on 15 th September 1973, aged 90.

It was during the I920s that King Gustaf first developed his interest in archaeology: he sponsored and also took an active part in Swedish expeditions to Greece and Cyprus. In 1926 he was the first to hold the famous Keishu Crown, discovered in a seventh-century grave excavated in Korea to mark his visit. He was also the only westerner ever to enter Peking, the 'Forbidden City', by the Wu Men Gate. King Gustaf became a leading European authority on Far Eastern art, and he was awarded honorary degrees and fellowhips of learned societies in many parts of the world. In this country, he held honorary degrees at the Universities of Oxford, Cambridge, Leeds, and London. He was a Fellow of the Royal Society, an Honorary Fellow of the British Academy, and was created a K.G. by the Queen during his state visit to London in 1954.

\section{PAUL DESCHAMPS}

\section{Elected Honorary Fellow and February 1928}

M. Deschamps died on 25th February 1974 at the age of 85 . He was a member of the Académie des Inscriptions et Belles-Lettres, a Commander of the Legion of Honour, and was Keeper of the Musée national des monuments français. In his academic interests he was torn between documentary research and archaeology, but eventually opted for the latter; his published work, however, reflected his historical knowledge.

He became Secretary to the Ecole de Chartes in 1921, and in 1927 was appointed Director of the Musée de sculpture comparée de Trocadéro. He took part in expeditions organized by the Director of Syrian Antiquities, and these led to the publication of the first volume of Chateaux des Croises (1934), dealing with Le Krak des Chevaliers, a second on the kingdom of Jerusalem (1939), and a third volume in 1972 on Tripoli and Antioch, all of which had great consequences 